\title{
Follicular Variant Thyroid Gland Papillary Carcinoma
}

National Cancer Institute

\section{Source}

National Cancer Institute. Follicular Variant Thyroid Gland Papillary Carcinoma. NCI

Thesaurus. Code C126594.

An encapsulated or nonencapsulated variant of papillary carcinoma of the thyroid gland characterized by the predominance of follicular structures. The malignant follicular cells display the nuclear features that characterize the papillary adenocarcinomas of the thyroid gland. 